\title{
DISPERSED AND DECENTRALISED SETTLEMENT SYSTEM
}

\author{
Andrej Černe \\ University of Ljubljana, Faculty of Arts, Department of Geography, \\ Aškerčeva 2, Ljubljana, Slovenia \\ e-mail: andrej.cerne@guest.arnes.si
}

\begin{abstract}
In the process of reintegration of the urban system new settlements are emerging on the urban rim, transitional zones are reurbanised, derelict areas within the cities are being developed and degraded urban areas of derelict industrial complexes are being renaturalised. In the periphery combined research and production parks are being set up, in the open landscape integrated business, trade and recreational centres are springing up. Decentralisation and recentralisation of focal points of development accompany the contemporary processes of reurbanisation and suburbanisation - they are simultaneous and move in two-direction i. e. to and from the city. We understand them as manifestation of a dynamic balance among contradiction existing between the centre and the rim. Deindustrialisation and relocation of production and distribution from the centres of gravity to the periphery generate extensive degraded urban areas within cities and between the city and suburbs. The periphery is being urbanised with the creation of new, dispersed and nonhierachical poles of development, and the city and inner city is undergoing reurbanization. The general environmental conditions in the city and in the countryside are being equalised, the potentials of development are being sought in the comparative advantages of local conditions: be it attractive urban districts, be it suburban entities or countryside areas.
\end{abstract}

Key words: settlement system, settlement pattern, dispersion, decentralisation, Slovenia

\section{THE CONCEPT OF DISPERSION AND DECENTRALISATION}

The early urban planners believed, that the comprehensive design of settlements and reconstruction of existing ones could best achieve amenity, convenience, safety and public health in urban form. At the beginning in 1900s E. Howard dreamed up his ideal of spatial unity in which donor city was surrounded by balanced constellation of settlements. The Soviet deurbanist of the 1920s, led by Ginsburg and Okhitovich argued, that electricity and new transportation technologies, above all the car, would allow cities to empty out. They argued 
for new kinds of built from based on factory-produced materials, with individual lighweight transportable homes located in natural countryside, thus creating a "townless, fully decentralised, and even populated country"; they even envisaged the eventual razing of the cities to form huge parks and urban museums (Hall, 1988). Peter Kroptkin, a geographer but also an anarchist, argued that new technologies were transforming, even abolishing, the tyranny of geography. Thirty years later, Munford and Steine held up other variations of complete regional harmony of city and surroundings as the paragon of urban form. Mumford puts in his appreciation of garden city alternative: "A modern city, no less than medieval town .... must have a definite size, form and boundary. It was no longer to be mere sprawl of houses along an indeterminate avenue that moved towards infinity and ended suddenly in a swamp" (Fishman, 1999). An overall model that rested on analogy between urban development and living beings as "complex systems" was based on central place theory, the rank-size rule, Pareto-distribution and gravity models. This was a continuation of prewar ideas about the city and/or region as a living organism. P. Geddes characterized urban development not in terms of spatial unity but as an urban labyrinthine complex. F. L. Wright regarded the metropolitan region not as a harmonious equilibrium of city and surroundings, but as fundamentally shaped by the actual behaviour of individuals. The spatial pattern that arose from this resulted in far-reaching decentralisation with innumerable movements to and from various scattered locations - the centre of Wright's metropolitan region was the individual himself. A theoretical model was designed for the population distribution according to the spatial pattern of different number of settlements with different number of inhabitants. In the first graph we have altogether 84 settlements in the second graph population is dispersed among 321 settlements. In the first graph we have just 27 settlements with 1000-2000 inhabitants, in the second graph there are 161 such settlements.

Figure 1: A theoretical model of the spatial pattern of population




This model was applied than to the concentrated, deconcentrated and concentrated-deconcentrated settlement spatial pattern (Faludi, 1994).

Figure 2: The concept of concentrated, deconcentrated and concentrated-deconcentrated settlement spatial pattern



Source: Faludi, 1994, 134

Concentrated deconcentration: this term referred to allowing people to live in suburban environments, but concentrating new development in and around existing towns and cities and in particular in a number of designed overspill centres. Concentrated deconcentration was to take place within the framework of city regions comprising both donor cities and overspill centres. From the visual perception we can determine two extreme spatial settlement pattern in the form of two different landscapes. The first with the scattered and dispersed spatial, economic and dwelling units and the second with the spatial organisation of these unit into the small spatial nuclei. 
Figure 3: The concept of dispersed and concentrated spatial settlement pattern






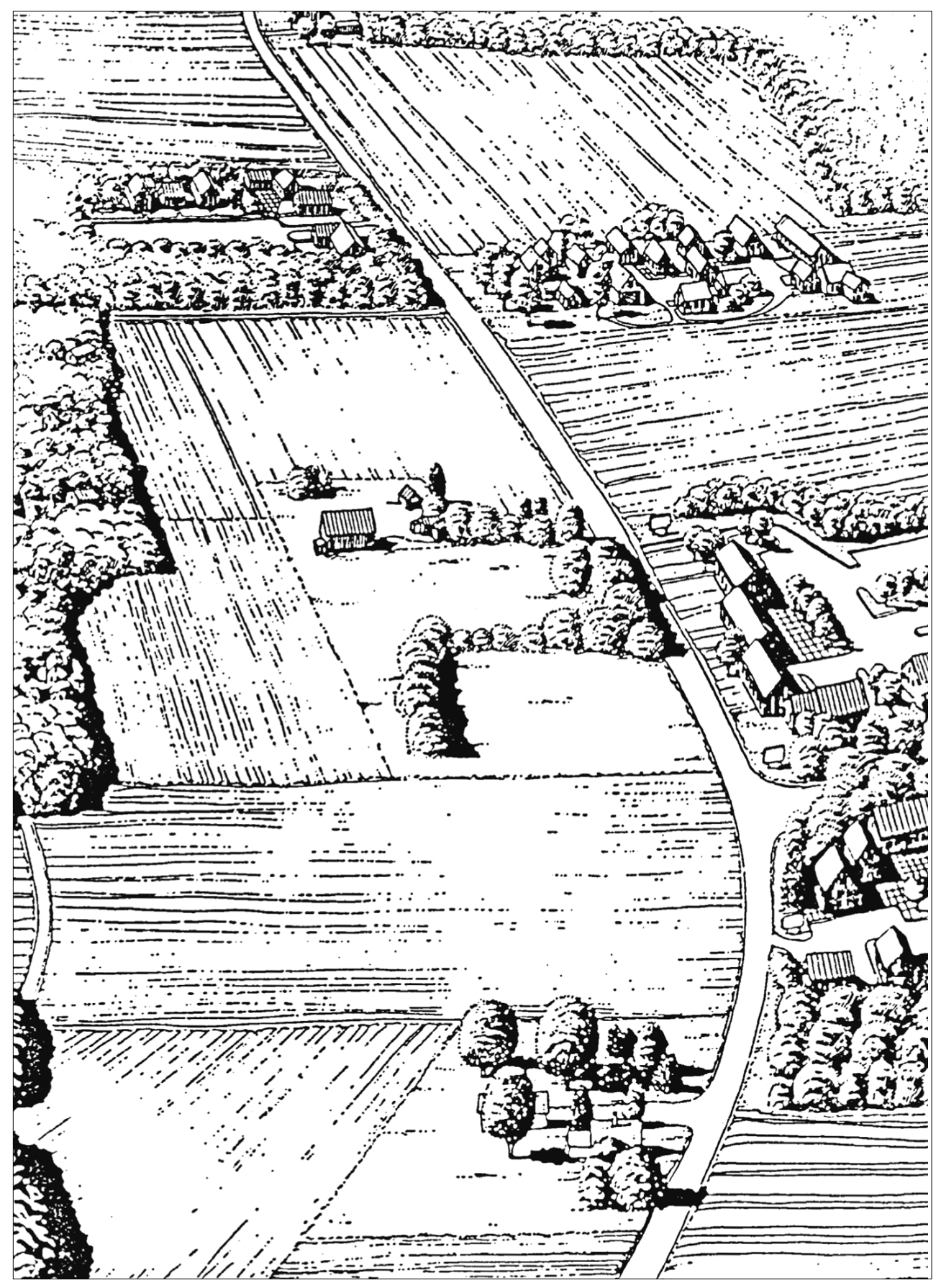

Source: Kaiser, 1995, 428, 429 
Within this came the crucial question: whether to concentrate development at higher densities within the existing urban envelope, or whether to encourage decentralisation to new areas or satellite communities. If we decentralise activities two contradictory things happen: commuter journeys are shortened, but there is a huge transfer from public transport to the private car. Overwhelming evidence now shows that exactly this was happening in major urban areas during the 1980s and 1990s. Typical urban areas have all decentralised homes and jobs, leading to a huge growth in suburb-to-suburb commuting and a corresponding shift from public transport to car.

The decentralised settlement structure is based on two extravagances: the waste of land inherent in single family house with its own garden, and the waste of energy inherent in the use of the car. This settlement structure is absolutely dependent on its road network, yet that network is almost always in a state of chaos and congestion. Commuting within the dispersed settlement is multi-directional, following the transport network pattern, which define community. This multiplicity of destinations make public transportation highly inefficient, but it does remove that bottleneck which necessarily occurred when work is concentrated at a single core within a region. Each house in dispersed settlement structure is within a reasonable driving time of a truly "urban" array of jobs and services, just as each workplace along the main road can draw upon an "urban" pool of workers.

The landscape of decentralised settlement structure is a mass of housing, industry, commerce, and even agricultural uses. Decentralised settlement system has no proper boundaries; however defined, it is divided into a separate and overlapping political jurisdictions, which make any kind of co-ordinated planning virtually impossible.

If there is a single basic principle in the structure of decentralised settlement, it is the renewed linkage of work and residence. The suburb separated the two into distinct environments; its logic was that of the massive commute, in which workers from the periphery travelled each morning to a single core and then dispersed each evening. The dispersed settlement contains both work and residence within a single decentralised environment. The dispersed settlement evolved its own pattern of transportation in which a multitude of relatively short journeys in a multitude of different directions substitutes for that great tidal wash in and out of a single urban core, which had previously defined commuting. With housing, jobs, and services all on the periphery, this sprawl develops its own form of relative efficiency. As both homes and jobs have decentralised, more and more journeys have transferred from public transport to the private car - especially for the fast-growing category of suburb-to-suburb journeys, where conventional public transport cannot easily compete. In these vast tracts of outer suburbia and rural exurbia, the car has already become the universal mode of transport, and a whole style of life has been developed around it.

The real centre of decentralised settlement structure is neither an urban nor a rural nor even a suburban area, but rather the decentralised urban region. The true centre of this new settlement structure is not in some centre but in each residential unit. From that central starting point, the members of the household create their own city from the multitude of destinations that are within suitable driving distance. One member of household might work at the industrial park, the other at an office complex in the other direction in urban centre; the children travel by bus to comprehensive school in near neighbourhood or drive 
themselves to the university; the family shops are at several different malls along several different transport roads; every weekend members of households drive 50-100 km to a seaside, alpine and rural area where they have a second house.

Spread out along motorway growth corridors are shopping malls, industrial parks, campus-like office complexes, hospitals, schools and a full range of housing types. Its residents look to their immediate surroundings rather than to the city for their jobs and other needs; and its industries find not only the employees they need but also the specialised services. Industries make up only a small minority of jobs but the very existence of the decentralised city is made possible only through the advanced communications technology which has so completely superseded the face-to-face contact of the traditional city. Urban diversity is generated without traditional urban centralisation. The dispersed settlement structure is truly multicentered.

This phenomenon, as remarkable as it is unique, is not subirbanisation but a new type of city characterised by simultaneous decentralisation of housing, industry, specialised services and office jobs; the consequent breakaway of urban periphery from central city it no longer needs; and the creation of a decentralised environment that nevertheless possesses all the economic and technological dynamism we associate with the city. Urban region is a series of urban settlements with small homes and factories set in open fields, yet connected by high speed rail transportation to any other point in the region. In the decentralised region functions are not classified by their distance from the centre, which in any case is becoming increasingly irrelevant to the city. The system of roads made possible a distribution of central elements throughout the urban areas. The new city required a massive and co-ordinated relocation of housing, industry and other "core" functions to the periphery; yet there were no co-ordinators directing the process.

As in the past, technological change will bring about not a general dispersal but a general reshaping of the spatial pattern. Throughout the nineteenth century, rail transportation had been a relatively simple system favouring direct access to large centres. With the spread of branchlines and electric tramways, however, a complex rail network had been created that could serve as the basis for a decentralised region. But there were other emerging networks, most notably electricity and the telephone. The electrical system gave every point in a region the some access to power as any other; the advantage of central location was accordingly diminished. In an analogous way, the telephone provided instant communication from any point to any other point in a region, thus eliminating the need for a central location and face-to-face contact. Neither industry nor business needed the great city any longer, and both would inevitably melt away to cheaper, secluded locations. Not only could industry produce its goods more cheaply and more efficiently away from the core; but businessmen would invariably choose to live in quiet country towns and conduct their business by telephone. Those activities capable of being decentralised will continue to disperse to back offices; some will end up in homes or local workstations. But other acti-vities will remain concentrated in face-to-face activity centres, though not always in their present locations: growth and decentralisation within large urban areas will produce a more polycentric pattern. At least some kinds of work and activities will continue to congregate in the cities, and even in their hearts; and that movements of people - for work, for pleasu- 
re, for social purposes - will continue to increase in and around these centres. Information society will mean that any activity that relies on a screen or telephone can be carried out anywhere. Information society will at least equalise the locational advantages of all places, allowing almost infinite decentralisation from higher-cost or less-efficient to lower-cost, more efficient ones, and thus transferring activity to wherever people happen to be. Some analysis indicate major reductions in commuting, especially at congested peak hours; substantial reduction in overall travel, including non-work trips; more reliance on local facilities, meaning less travel; but a minority of telecommuters moving further from central cities, raising the pattern already calling telesprawl (Hall, 1998).

There are many points of attack on suburbia: waste land, increased commuting times, higher service costs, lack of parking places. But the central criticism is that the suburbs lack form. In the suburban landscape "each building is treated in isolation, nothing binds it to the next one". Decentralisation destroys both "nature" in its natural form and "society" in its civil form (Keil, 1998). Lynch wrote a devastating critique of the complete and tensionfree models of spatial order. He especially mocked the organic metaphors planners used to describe metropolitan areas as well as the functional concepts of urban development such as urban systems - because they cannot be traced back to the real world, and more importantly, ignore the recalcitrant relationships which surround urban development. Lynch urged planners to abandon the ideal of comprehensive spatial unity and embrace a number of specific quality dimensions to guide new strategies (Lynch, 1981). Friedmann in his essay on the future of urban habitat beyond the industrial city wrote about "the urban field as an artificial environment". Farms and forests are interspersed with clustered urban settlements and centres of productive work. But the land is no longer primeval: in a fundamental way, whether its use is agriculture or not, it has become "urbanised" (Friedmann, 1973). The nature of the city is that it turns nature to the city; what is considered urban today has extended beyond what we used to recognise as the contiguous city. Lynch urged planners to abandon the ideal of comprehensive spatial unity and embrace a number of specific quality dimensions to guide new strategies. (Faludi) More recent attention has been given to the sustainability of alternative urban forms and to relative merits of high and low-density development.

More recent attention has been given to the sustainability of alternative urban forms and to relative merits of high and low-density development.

On the plus side of suburbanisation is that it is a process of extraordinary vitality, producing millions of new homes and hundreds of shopping districts and thus contributing to national economic growth; it produces a lot of rather good housing and of rather pleasant neighbourhoods.

While the urban cannot be understood in isolation from its immediate regional hinterland, it can also not be understood outside of its global context. The social, spatial and ecological structures of the world cities result from globalised economic dynamics in which cities and their environments now have to be understood. Global economy requires a global spatial system composed of urban networks organized into hierarchy of node. Friedman's World City hypothesis posited that the form, function and relative status of a given city are 
directly related to its degree of integration into global urban hierarchy which, in turn reflected the relative degree of global economic power it was able to host. (Douglass, 1998)

For example, urban networks as urban areas are described as the engines of economic growth and employment generators. The components of the urban areas were "urban regions", the flows of goods, people and information, and the hard as well as the soft links between them. Networks of urban regions existed on the two spatial scales, the regional and the scale of Europe as a whole. The emergent European urban network consisted of urban agglomerations and regional networks of international significance. A distinction was determined between two core zones in Europe on the one hand and the peripheral regions on the other. In the core zones, congestion and environmental degradations were the major problems. In the peripheral areas, connections were inadequate. Both problems needed to be addressed. This was also true for problems within the cities. Cities were essential links and such they needed assistance in coping with environmental and social problems. Polycentric development was the preferred method reflecting this view. Because of their spatial and environmental qualities, a special role for medium-sized cities was determined (Faludi, 2002). So the threefold task was to improve the economic, social and environmental quality of cities, to improve physical links in a more environmentally friendly and sustainable way and to foster co-operation. Spatial balance as a key concept amounted to a decentralised urban system based on three basic principles: these were identified as urban spread, the development of corridors and the appropriate use of energy and transport.

\section{SLOVENIA}

A Slovene characteristic is the large dispersion of settlements, since only a good half of the population lives in cities. A little under two million people live in almost 6000 settlements; only two largest have more than 100.000 inhabitants. Natural conditions and historical development are the main reasons that towns are relatively small and that there are so many villages. Almost one half of population lives in rural areas, although only a good $4 \%$ survive of farming alone; the rest communicate daily to employment centres, as a rule, cities or settlements with urban characteristics.

A steady increase in the number of inhabitants creates areas of concentration, while a steady decrease in the number of inhabitants due to negative natural increase and/or negative migration creates areas of depopulation or the thinning out population. Depopulation affects two thirds of the territory, heavy depopulation one half and weak depopulation one fifth. Population density in Slovenia is 97 people $/ \mathrm{km}^{2}$. Due to the diversity of regions, the population density according to the regions is irregular. According to the relief, areas of plains and sunny hilly regions, or altitude belts up to 400 metres have above-average population density. $75 \%$ of inhabitants is living in concentration areas, where an average density is 237 inhabitants per $\mathrm{km}^{2}, 8 \%$ in stagnation areas with only 37 inhabitants per $\mathrm{km}^{2}$ and $18 \%$ in decreasing areas with the lowest density, only 35 inhabitants per $\mathrm{km}^{2}$. Concentration areas comprise $31 \%$ of the territory and $34 \%$ of all settlements, areas of stagnation $20 \%$ 
of the territory and the some percent of settlements and decreasing areas present half of territory and $46 \%$ of all the settlements (Černe, 2001).

Between 1966 and 1994, Slovenia officially had no "towns", since this legal term was abandoned in the 60 's, after the introduction of the "communal" system. Slovenian towns have of course a rich historical heritage: many of them where built on Roman ruins. Almost all of them origin either in medieval cities or medieval market towns or local rural centres. Some towns were built as industrial or mining cities in the $19^{\text {th }}$ century. Two towns were built as new towns after the Second World War. Because the need to specify towns still existed, such specification was made by the Republic's Statistical Office and occurred under the name "urban settlements". The list included all bigger settlements that had already been recognised as towns in the past, and some intensely urbanised settlements that were close to the towns. The list comprised 73 settlements, 58 of which were true towns and 15 were urbanised settlements.

More than two thirds of half of inhabitants that are living in urban settlements are living in suburban areas. We have approximately just 180 settlements that can be determined as urban settlements according to the three criteria: the number of inhabitants, more than 2.000 , the built up areas and density, at least three ha of areas with the density of more than 50 parsons per ha. In 14 "town regions" on $15 \%$ of the territory live $75 \%$ of inhabitants who manage more than $80 \%$ of the economic potential and have $88 \%$ of all the employed (Strategija, 2002).

According to the definition that central settlement is the settlement with more than 50 registered activities in the settlement, there are 294 central settlements. There are only 13 settlements $(0,22 \%$ of all the settlements) with more than 1.000 registered activities in the settlement, 48 , or $0,81 \%$ with more than 300 , and 233 or $4 \%$ settlements with more than 50 registered activities in the settlement. There is at least one activity in $79 \%$ of settlement. According to the number of activities in the settlements and urban centres, communal centres and towns, it is possible to determine three typical thrasholdes as the basis for degree of centrality of urban centres within the settlement network (Černe, 2002).

As concerns the settlement system and urban network spatial unevenness in urban network is manifested through inadequate position of centres within the areas, or through inadequate spatial division of regions, their size and furnishing. Namely, the urban network structure lacks centres of adequate size, which could have synergetic influence on economic deve-lopment and greater concentration of infrastructure and could be reasonably furnished with public utilities. The problem of uneven spatial distribution of economic and social infras-tructures, and structural asymmetries between individual regions and regional centres are manifested as poorer accessibility to individual areas and settlements, extensive daily mi-grations and inefficient, expensive and deficient infrastructural. Poor accessibility to high-level services is very typical of border areas, which is all due to the deficient distribution of functions among the settlements within the settlement system.

The origins of problems are to be found also in the typical dispersed settlement pattern, which makes a reasonable system of infrastructure and public utilities or useful land use. The dispersion of settlements and activities contributes to intensified use of natural resources on various locations and increases the extent of transport. Functional division of towns 
is inadequate; the level of urbanity is low which results in unreasonable infrastructu-re of public utilities. Extensive degraded mining, industrial, inferior housing areas have developed. The problems are concerned with non-structural growth of towns and other settlements, unreasonable use of building and transport areas in settlements, and partial urban planning.

Figure 4: The settlemet pattern of the Litoral Area of Slovenia in the 60s

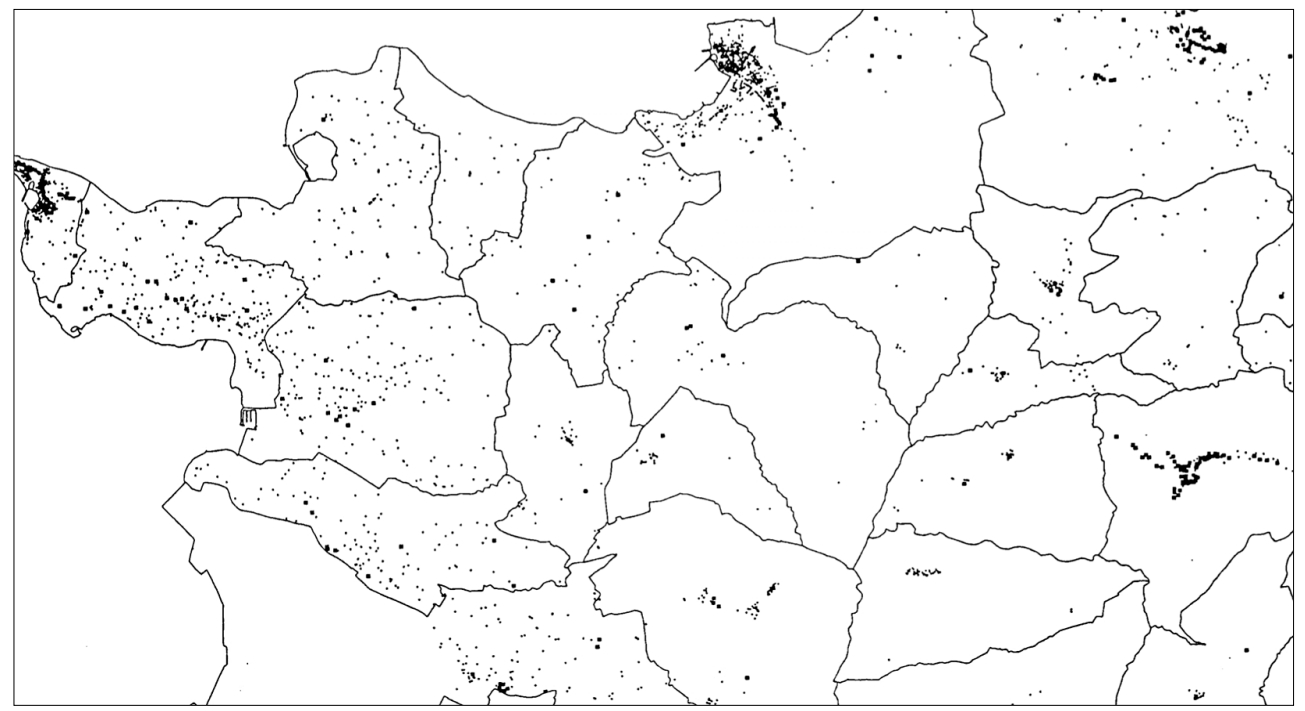

The settlement pattern of the Litoral Area of Slovenia in the $90 \mathrm{~s}$

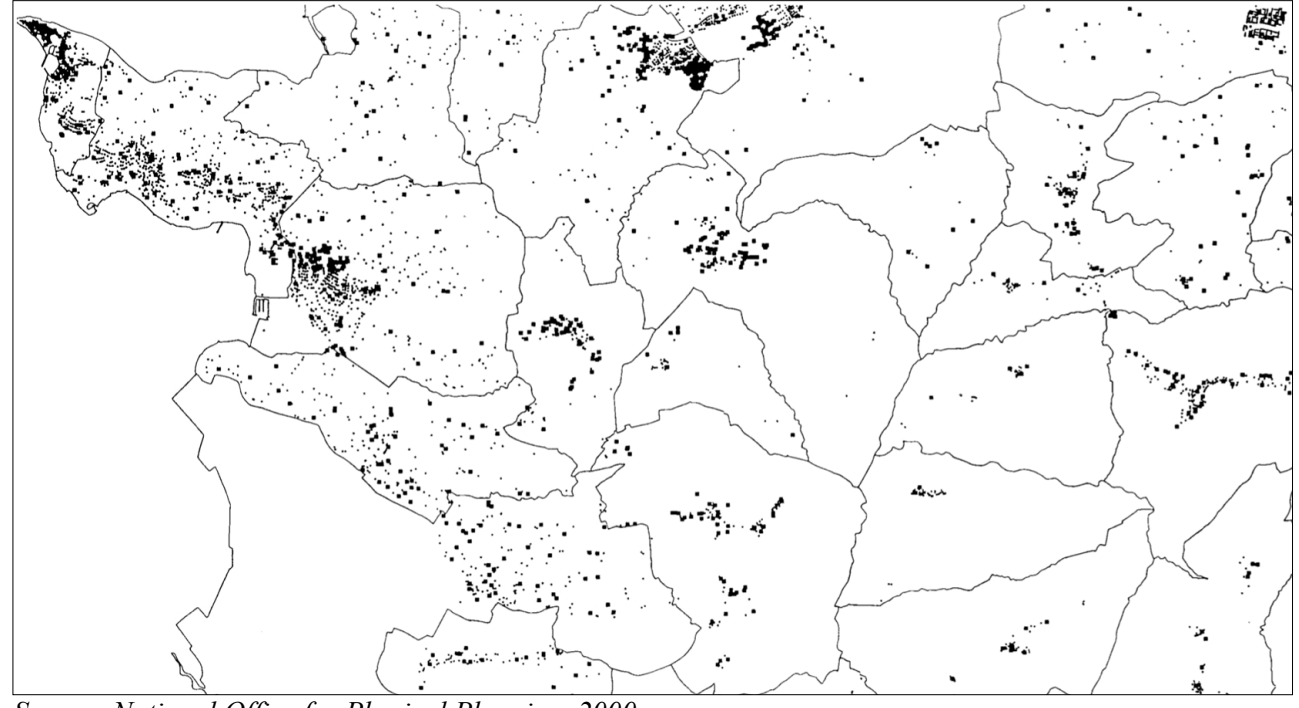

Source: National Office for Physical Planning, 2000 
Suburbia is equalised with the spatial dispersion. Spatial dispersion is evident on the two levels. At the level of the settlement, a great number of small settlement or towns and at the level of settlement with dispersed building.

In the process of reintegration of the urban system new settlements are emerging on the urban rim, transitional zones are reurbanised, derelict areas within the cities are being developed and degraded urban areas of derelict industrial complexes are being renaturalised. In the periphery combined production and research parks are being set up, in the open landscape integrated business, trade and recreational centres are springing up. Decentralisation and recentralisation of focal points of development accompany the contemporary processes of reurbanisation and suburbanisation - they are simultaneous and move in twodirection i. e. to and from the city. We understand them as manifestation of a dynamic balance among contradiction existing between the centre and the rim. Deindustrialisation and relocation of production and distribution from the centres of gravity to the periphery generate extensive degraded urban areas within cities and between the city and suburbs. The periphery is being urbanised with the creation of new, dispersed and nonhierachical poles of development, and the city and inner city is undergoing reurbanization. The general environmental conditions in the city and in the countryside are being equalised, the potentials of development are being sought in the comparative advantages of local conditions: be it attractive urban districts, be it suburban entities or countryside areas. Due to the deregulation of planning instruments and ownership relations and due to the absence of effective land policy, by which municipalities could increase the land supply and achieve market prices for land, today cities are powerless when implementing the non-profit public use. The building land market is not developed; a small number of owners prevail with their monopolistic attitude. It is therefore logical to assume that in urban areas an ever-greater number of building plots will remain disuse or will stagnate because of fictions and speculative use. Under open market economy when municipalities remain without any instruments of compulsory planning for asserting the public interest, and they lack resources for boosting development, it becomes impossible to affirm the understanding that rehabilitation of degraded urban areas are de facto primary forms of urban development.

Stagnation in housing standard results from insufficient offer of non-profitable, subsidised and proprietorial housings and building plots. Increased is the rush on broader urban hinterlands and quality landscape areas, also demonstrated through illegal building. The problems of housing and public utility construction are related to: too slow revitalisation and inefficient substitution of substandard housing; to inefficient saving for and financing of housing; undeveloped land policy and non-collecting of land/urban rent; inadequate quality of architecture and urban planning and insufficient construction; renovation and maintenance of public utility facilities and installations.

\section{References}

Černe, A. 2001: Analiza prostorskih razvojnih možnosti Slovenije. Raziskovalna naloga, Ministrstvo za okolje in prostor, Urad republike Slovenije za prostorsko planiranje, Ljubljana. 
Černe, A. 2002: Analiza stanja in trendov prostorskaga razvoja Republike Slovenije. Raziskovalna naloga, Ministrstvo za okolje in prostor, Urad republike Slovenije za prostorsko planiranje, Ljubljana.

Douglass, M., Friedmann, J. 1998: Cities for Citizens. Planning and the Rise of Civil Society in a Global Age. John Wiley and Sons, Chichester.

Faludi, A., Waterhout, B. 2002: The Making of the European Spatial Development Perspective. No Masterplan, The RTPI Library Series, London.

Faludi, A., Valk, A. 1994: Rule and Order. Dutch Planning Doctrine in the Twentieth Century. Kluwer Academic Publishers, Dordrecht.

Fishman, R. 1999: Urban Utopias in the Twentieth Century. The MIT Press, Cambridge.

Friedmann, J. 1973: The Future of the Urban Habitat. The Place of Planning. Auburn University Printing Service, $105-141$.

Hall, P. 1998: Cities in Civilization. Pantheon Books, New York.

Hall, P. 1988: Cities of Tomorrow. An Intellectual History of Urban Planning and Design in the Twentieth Century. Blackwell, Oxford.

Kaiser, E.J., Godschalk, D.R., Chapin, F.S. 1995: Urban Land Use Planning. University of Illinois Press, Illinois.

Keil, R. 1998: Greening the Polis or Policing Ecology? Local Environment Politics and Urban Civil Society in Los Angeles. In: Douglass, M., Friedmann, J. (1998) Cities for Citizens. Planning and the Rise of Civil Society in a Global Age. John Wiley and Sons, Chichester, $91-105$.

Lynch, K. 1981: A Theory of Good City Form. The MIT Press, Cambridge.

Strategija prostorskega razvoja Republike Slovenije, 2002: Interno gradivo, Ministrstvo za okolje in prostor, Urad Republike Slovenije za prostorsko planiranje, Ljubljana 